\title{
ESSENTIAL OIL CHEMICAL COMPOSITIONS OF THE FRUIT AND SEEDS OF THE ENDEMIC SPECIES PYCNOCYCLA BASHAGARDIANA MOZAFF.
}

\author{
MELIKA CHEHRAZIMEYDAN ${ }^{1}$, JINOUS ASGARPANAH ${ }^{2,3 *}$ \\ ${ }^{1}$ Herbal Medicines Research Center, Pharmaceutical Sciences Branch, Islamic Azad University, Tehran - Iran (HMRC). \\ ${ }^{2}$ Young Researchers and Elite Club, Pharmaceutical Sciences Branch, Islamic Azad University, Tehran, Iran. \\ ${ }^{3}$ Department of Pharmacognosy, Faculty of Pharmacy, Pharmaceutical Sciences Branch, Islamic Azad University, Tehran-Iran (IAUPS).
}

\begin{abstract}
The essential oil contents in the fruits and the seeds of the endemic species Pycnocycla bashagardiana growing wild in south of Iran was found to be $0.2 \%$ and $0.4 \%$ respectively based on the fresh weight. The oils were analyzed by gas chromatography (GC) and GC-mass spectrometry (GC-MS). Twelve and thirty constituents were identified, which approximately constituted $90.5 \%$ and $94.0 \%$ of the fruits and the seeds oils, respectively. The phenyl propanoid myristicin was found to consist more than $65 \%$ of both oils.
\end{abstract}

Keywords: Pycnocycla bashagardiana, Fruit, Seed, Essential oil, GC/MS

\section{INTRODUCTION}

Plants belong to Apiaceae family are rich in secondary metabolites and embodies numerous genera of high economic and medicinal value, yielding flavonoids, coumarins, acetylenes, terpenes and essential oils [1]. It is well known that occurrence of essential oils and oleoresins is a characteristic feature of this family [2].

Pycnocycla is the genus belonging to Apiaceae family, Apioideae subfamily, Echinophoreae tribe and comprising about 20 species of herbaceous perennial, multicaulis and spinous plants widely distributed in tropical and subtropical regions [3]. Pycnocycla is represented by eight species in Iran all of which are native or endemic [4]. Some reports on phytochemical analyses of this genus can be found in the literature. The chemical compositions of the essential oils from the aerial parts of $P$. nodiflora Decne. ex Boiss. [3], P. aucherana Decne. ex Boiss. [5], P. spinosa [6,7], P. musiformis [8], P. bashagardiana [9] and $P$. flabellifolia (Boiss.)Boiss. [1] have been previously studied. Literature survey revealed just one report on the essential oil composition of the seeds and fruits of Pycnocycla genus ( $P$. nodiflora) $[10]$ and there was no attempt to study the essential components of $P$. bashagardiana fruits and seeds up to now. Regarding it and significant pleasant odor of the fruits and seeds, we were prompted to investigate the essential oil composition of these parts of $P$. bashagardiana for the first time.

\section{EXPERIMENTAL}

\section{Plant material}

Fresh fruits and seeds of $P$. bashagardiana were collected in October 2014 from Bashagard village, Jask County, Hormozgan Province, Iran: $\left(25^{\circ} 38^{\prime} 38^{\prime \prime} \mathrm{N}, 57^{\circ} 46^{\prime} 28^{\prime \prime} \mathrm{E}, 900 \mathrm{~m}\right)$. Specimens were identified by R. Asadpour and vouchers were deposited in the Herbarium of Pharmaceutical Sciences Branch, Islamic Azad University (IAUPS), Tehran under code numbers 5067AUPF and 5068-AUPF respectively. Seeds were removed out of the fruits and both were separately submitted to hydrodistillation in a Clevenger-type apparatus for 3 hours. At the end of distillation the oils were collected, dried with anhydrous $\mathrm{Na}_{2} \mathrm{SO}_{4}$, measured, and transferred to clean glass vials and kept at a temperature of $-18^{\circ} \mathrm{C}$ for further analyses.

Analysis of the essential oil

Oil sample analyses were performed on a Hp-6890 gas chromatograph (GC) equipped with a FID and a DB-5 capillary column, $30 \mathrm{~m} \times 0.25 \mathrm{~mm}, 0.25$ $\mu \mathrm{m}$ film thickness, temperature programmed as follows: $60^{\circ}-240^{\circ} \mathrm{C}$ at $4^{\circ} \mathrm{C} /$ min. The carrier gas was $\mathrm{N}_{2}$ at a flow of $2.0 \mathrm{ml} / \mathrm{min}$; injector port and detector temperature were $250^{\circ} \mathrm{C}$ and $300^{\circ} \mathrm{C}$, respectively. Samples were injected by splitting and the split ratio was 1:10.

GC/MS analysis was performed on a Hewlett-packard $6890 / 5972$ system with a DB-5 capillary column $(30 \mathrm{~m} \times 0.25 \mathrm{~mm} ; 0.25 \mu \mathrm{m}$ film thickness. The operating conditions were the same conditions as described above but the carrier gas was He. Mass spectra were taken at $70 \mathrm{eV}$. Scan mass range was from $40-400 \mathrm{~m} / \mathrm{z}$ at a sampling rate of $1.0 \mathrm{scan} / \mathrm{s}$. Quantitative data were obtained from the electronic integration of the FID peak areas. The components of the oils were identified by their retention time, retention indices, relative to
C9-C28 n-alkanes, computer matching with the WILEY275.L library and as well as by comparison of their mass spectra with data already available in the literature $[11,12]$. The percentage of composition of the identified compounds was computed from the GC peaks areas without any correction factors and was calculated relatively. The analyses of both essential oil are the average of three replicates for each.

\section{RESULTS AND DISCUSSION}

The hydrodistillation of the fruit and seeds of $P$. bashagardiana gave pale yellow oils with pleasant odor and yields of $0.2 \%$ and $0.4 \%(\mathrm{v} / \mathrm{w})$ respectively.

Table 1: GC-MS analysis of $P$. bashagardiana fruit and seeds essential oils.

\begin{tabular}{|c|c|c|c|c|}
\hline Compound $^{\mathrm{a}}$ & $\mathrm{KI}^{\mathrm{b}}$ & $\mathrm{KI}^{\mathrm{c}}$ & $\%$ (fruits) & $\%$ (seeds) \\
\hline 1. $\alpha$-Pinene & 938 & 939 & - & 0.7 \\
\hline 2. Sabinene & 973 & 975 & 1.4 & - \\
\hline 3. $\beta$-Pinene & 978 & 979 & 1.2 & 8.1 \\
\hline 4. Myrcene & 990 & 991 & - & 0.5 \\
\hline 5. $\alpha$-Phellandrene & 1001 & 1003 & - & 0.4 \\
\hline 6. $\Delta$-2-Carene & 1002 & 1004 & - & 2.1 \\
\hline 7.p-Cymene & 1022 & 1025 & - & 0.3 \\
\hline 8. $\beta$-Phellandrene & 1028 & 1030 & - & 0.7 \\
\hline 9.Z- $\beta$-Ocimene & 1035 & 1037 & 1.1 & 1.7 \\
\hline 10.E- $\beta$-Ocimene & 1050 & 1050 & 4.0 & 1.4 \\
\hline 11.Terpinolene & 1087 & 1089 & - & 0.1 \\
\hline 12.Undecane & 1097 & 1100 & - & 2.4 \\
\hline 13.trans-Pinocarveol & 1137 & 1139 & - & 0.1 \\
\hline 14.Myrtenal & 1193 & 1196 & - & 0.1 \\
\hline 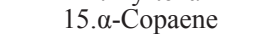 & 1375 & 1377 & - & 0.1 \\
\hline 16. $\beta$-Cubebene & 1392 & 1391 & 1.4 & 0.7 \\
\hline 17.Methyl eugenol & 1400 & 1401 & 1.3 & 0.4 \\
\hline 18. $\beta$-Caryophyllene & 1418 & 1419 & - & 0.1 \\
\hline 19. $\beta$-Cedrene & 1420 & 1421 & - & 0.5 \\
\hline 20. $\alpha$-Guaiene & 1442 & 1440 & 1.4 & 1.6 \\
\hline 21. $\alpha$-Humulene & 1453 & 1455 & - & 0.3 \\
\hline 22.E- $\beta$-Farnesene & 1457 & 1457 & - & 0.1 \\
\hline 23. $\beta$-Selinene & 1488 & 1490 & - & 0.1 \\
\hline 24. $\delta$-Guaiene & 1506 & 1508 & 1.1 & - \\
\hline 25.Myristicin & 1521 & 1520 & 73.5 & 67.0 \\
\hline 26.Elemicin & 1542 & 1540 & - & 1.1 \\
\hline 27. Caryophyllene oxide & 1583 & 1583 & 0.7 & 0.2 \\
\hline 28.Isomyricticin & 1622 & 1624 & 1.1 & 0.9 \\
\hline 29. $\beta$-Eudesmol & 1649 & 1651 & 2.3 & 0.7 \\
\hline 30.Geranyl hexanoate & 1720 & 1722 & - & 1.1 \\
\hline 31.Apiol & 1678 & 1678 & - & 0.4 \\
\hline 32. $\beta$-Sinensal & 1701 & 1706 & - & 0.1 \\
\hline Total & & & 90.5 & 94.0 \\
\hline
\end{tabular}

${ }^{\mathrm{a} C}$ Compounds listed in order of elution.

${ }^{b} \mathrm{KI}$ (Kovats index) measured relative to $n$-alkanes $\left(\mathrm{C}_{9}-\mathrm{C}_{28}\right)$ on the nonpolar DB-5 column under condition listed in the experimental section.

'KI, (Kovats index) from literature. 
Table 1 shows the list of compounds whose GC/MS concentration is not less than $0.1 \%$ of total peak concentration.

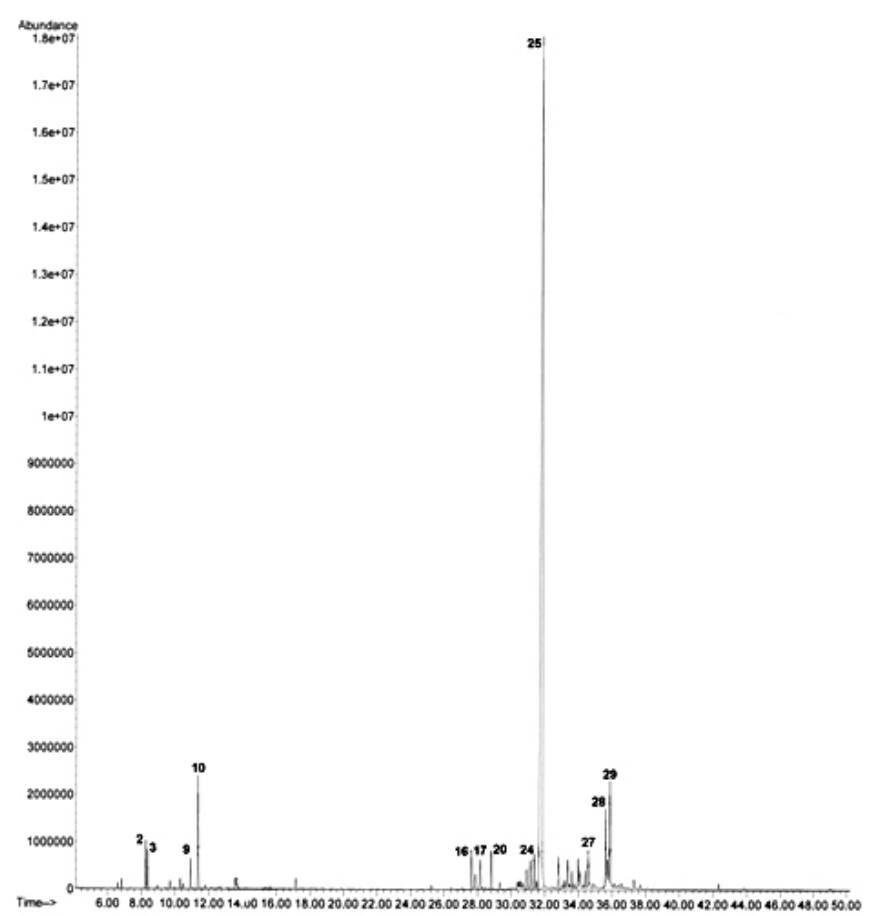

Figure 1. The gas chromatogram of $P$. bashagardiana fruits essential oil.

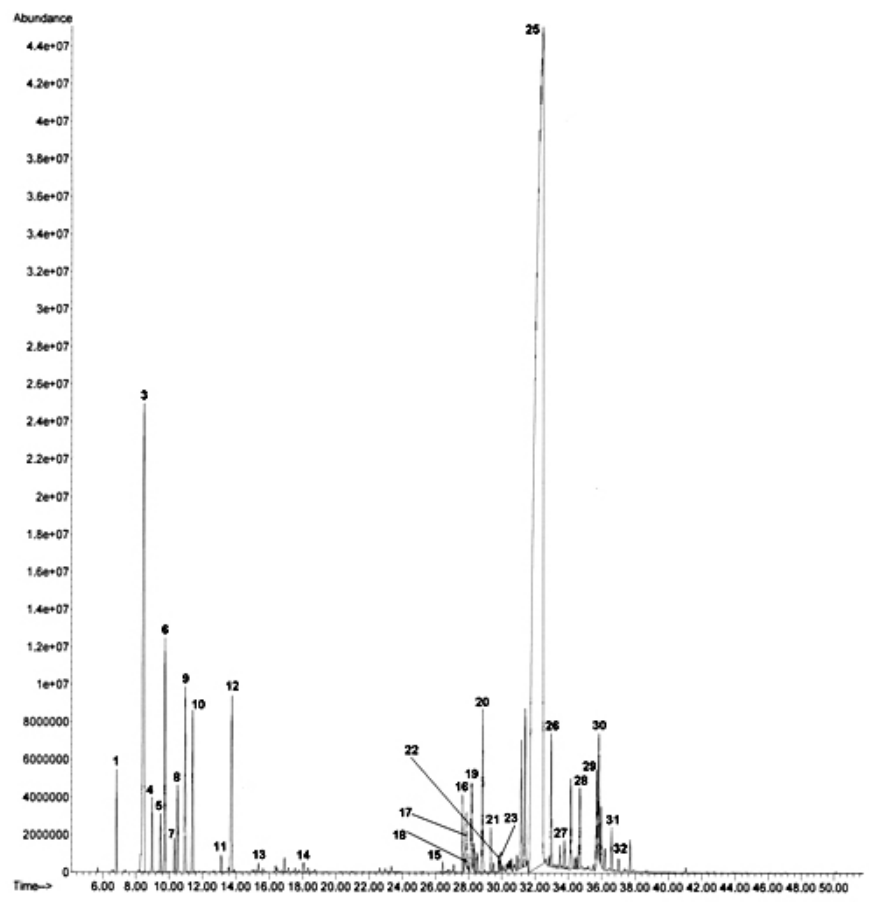

Figure 2. The gas chromatogram of P. bashagardiana seeds essential oil.

Twelve and twenty thirty components were identified in the fruits and seeds oils respectively which presented about $90.5 \%$ and $94.0 \%$ of the total compositions. The major constituents of both oils were characterized as myristicin. It was found to consist $73.5 \%$ and $67.0 \%$ of the fruits and the seeds oils respectively caused both oils to be known as rich natural sources of myristicin. Myristicin is a phenylpropanoid compound present in small amounts in the essential oil of nutmeg and to a lesser extent in other spices such as parsley and dill. It was reported that myristicin possesses a broad spectrum of biological activities including anti-inflammatory [13], anticarcinogenic [14] and cancer chemopreventive [15] effects. Possible neurotoxic effects on cultivated human neuroblastoma (cancer) cells were shown by Lee et al. [16]. Significant hepatoprotective activity of myristicin has been also shown [17]. Moreover myristicin is known as a naturally occurring insecticide [18]. Regarding highly presence of myristicin in P. bashagardiana fruits and seeds oils, observing these actions from the current oils is expectable.

\section{CONCLUSIONS}

This paper presents the essential oil chemical compositions of $P$. bashagardiana fruits and seeds for the first time. Due to the presence of myristicin as the major component in both oils, future studies on the biological and pharmacological properties of the oils especially the seeds oil are suggested.

\section{ACKNOWLEDGEMENTS}

Supports from the Pharmaceutical Sciences Branch, Islamic Azad University (IAUPS) are gratefully acknowledged.

\section{REFERENCES}

1. M. Yari, Z. Aghjani, S. Masoudi, A. Monfared, A. Rustaiyan, Daru, 7, 1 (1999).

2. K. H. Kubeczka, Aromatic plants, basic and applied aspects, Martinus Nijhoff Publishers, The hague, Boston, London, 1982.

3. K. Javidnia, R. Miri, M. Soltani, A. R. Khosravi, J. Essent. Oil Res, 20, 502 (2008).

4. V. Mozaffarian, A Dictionary of Iranian Plant Names. Farhang Moaser Publications, Tehran, Iran, 2005.

5. M. B. Teimouri, A. Shaabani, F. Sefidkon, J. Essent. Oil Res, 17, 473 (2005).

6. G. Asghari, G. Houshfar, Z. Mahmoudi, Daru, 9, 28 (2001).

7. L. Ahmadi, M. Mirza, J. Essent. Oil Res, 10, 197 (1998).

8. M. R. Akhgar, M. Khodashenas, H. Salari-Dehshikh, Trend. Mod. Chem, 4, 6 (2012).

9. E. Abbasi, O. Ghorban Dadras, J. Asgarpanah, J. Essent. Oil Res, 26, 502 (2014).

10. M. Nasr, J. Asgarpanah, Nat. Prod. Commun, 9(12), 1781 (2014).

11. A. A. Swigar, R. M. Silverstein, Monoterpenes, WI: Aldrich Chemical Company Publication, Milwaukee, USA, 1981.

12. R. P. Adams, Identification of Essential Oil Components by Gas Chromatography/Mass Spectroscopy. Allured Publishing Co., Carol Stream, IL, 1995.

13. J. Y. Lee, W. Park, Molecules, 16, 7132 (2011).

14. G. Q. Zheng, P. M. Kenney, L. K. T. Lam, J. Agri. Food Chem, 40, 107 (1992).

15. G. Q. Zheng, P. M. Kenney, J. Zhang, L. K. T. Lam, Carcinogen, 13, 1921 (1992).

16. B. K. Lee, J. H. Kim, J. W. Jung, J. W. Choi, E. S. Han, S. H. Lee, K. H. Ko, J. H. Ryu, Toxicol. Lett, 157, 49 (2005).

17. T. Morita, K. Jinno, H. Kawagishi, Y. Arimoto, H. Suganuma, T. Inakuma, K. Sugiyama, J. Agri. Food Chem, 51, 1560 (2003).

18. S. Srivastava, M. M. Gupta, V. Prajapati, A. K. Tripathi, S. Kumar, Pharm Biol, 39, 226 (2001). 